\title{
Special issue on economic analysis of law, politics, and regions
}

\author{
Moriki Hosoe $^{1}$
}

Published online: 8 November 2017

(C) The Japan Section of the Regional Science Association International 2017

It is a great honor to have the opportunity to organize this special issue in the second issue of a new journal. The progress of regional science has been remarkable, and the possibilities for the future are immeasurable. In particular, this journal is published in relation to the remarkable economic development of the Pacific and Asian. As global economy develops, institutional conflicts and policy conflicts among regions (including nations) have been occurring, including legal systems and political systems. These conflicts trigger many domestic reforms and several policy coordinations among regions. Considering these situations, this special issue is titled by "Economic Analysis of Law, Politics, and Regions".

This special issue of APJRS consists of twelve articles. The first two articles are devoted to political studies as a breakthrough frontier of regional science. The following four articles empirically deal with regional politics and regional economic problems in the development of Asian regions and nations. In addition, the following four articles deal with the influence on the economic development of legal regimes in the context of law and economics. In the last two articles, the regional development problem that globalization brings are treated from the perspective of risk governance and declining birthrate, respectively. I will briefly sketch the main features of these articles.

The first article in this special issue, written by Hori (2017), examines a theory of the intergenerational transmission of the cultural value of secularism and its interaction with the endogenous regime shifts between democracies and dictatorships. This is the outcome of new political economics on regional conflicts. It gives a great suggestion when we investigate about political dynamics of regions from the point of view of regional science.

Moriki Hosoe

hosoe@kumagaku.ac.jp

1 Department of Economics, Kumamoto Gakuen University, Kumamoto, Japan 
The second article proposed by Sato (2017) examines the referendum strategy and possibility of secession in multi-cultural country, and demonstrates that a domino effect induces sequential secession when neighboring regions are more independent. Since referendums have been today held on separation and independence in several countries, this research is very ambitious and hot study.

The second part is to investigate several economies in Asia from a point of political economics. Brehm and Svensson (2017) analyze the role of interjurisdictional competition for environmental law enforcement in China. The patterns of compliance with environmental transparency legislation are shown. In particular, the emerging jurisdictional interaction is in line with a Tiebout sorting process, where cities compete with diverse factor package to attract an optimal amount of investments.

Fukushige and Shi (2017) investigate intergovernmental fiscal relationships between the central government and provincial governments in China, with using non-symmetric Nash solution. They find that although an increase in either income inequality revenue or real per capita GDP lowers local governments' bargaining power with the budgetary system.

Stressing on regional stability and improvement, Choi and Kim (2017) examines a regional employment growth policy in Korea. Considering the effect of lagged employment, they suggest that regional employment growth policy in Korea requires a strategy for job stabilization and creation by improving workers' productivity in the long-run.

Most nations have experienced internal armed conflicts in the last several decades. In Cambodia, land mines are an unfortunate by-product of the prolonged civil wars, causing disabling numerous people. Using the Cambodia socio Economic Survey 201, Kang (2017) shows that one of significant reasons behind substantial poverty among Cambodians is disability especially caused by war.

Third part of this special issue is devoted to research of regional developments and conflicts from the point of law and economics. Suzuki et al. (2017) propose the possibility of social justice seeking in developing countries. Justice-seeking might be desirable when it lessens the degree of unfair treatment. However, they illustrate that it might not always lead to the institutions that ensure better distributive justice from the cases of Myanmar and Sri Lanka.

Efficient operation of the justice system is necessary for the sound development of society. Kim and Byeon (2017) points out that Discrepancy in the prosecution efforts between regulatory crimes and conventional crimes has widened significantly in Korea in the past 40 years. He shows that the opportunity cost of the politically motivated prosecuting focus has been borne in a disproportionate fashion, and prosecutions have discretionarily increased the use of summary prosecution for conventional crimes.

Though under Japanese tort law, the main purpose of damages is the compensation of a victim; do ordinary people support this idea? Mori et al. (2017) investigate how the legal system of damage is perceived by means of a survey from the point of comparative judicial system. They find that although most consider compensation when they estimate the appropriate amount of damages, many consider deterrence and punishment as well. 
Disaster does enormous damage to the regional economy. Then adequate provision of insurance is necessary under the reinsurance market. Nakaizumi and Yano (2017) demonstrate the commitment effect of a hard budget constraint by letting many small-size reinsurers assume reinsurance, instead of a single huge reinsurance company from the point of game theory. This means that for small-size reinsurers, the default risk will be high and it will be necessary for the primary insurance company to conduct an appropriate investigation.

The last part of this special issue is to investigate regional governance and regional disparity. As global markets grow and come to be connected firmly, the risk that some local difficulties might grow and transform into global crises is rising. Tanaka (2017) shows that regional competition diversifies regional risk governance to facilitate the reconstruction of infrastructure in shrinking cities for a new industrial revolution.

Finally, introducing precautionary public health policy into an overlapping generation model with migration of between regions, Naito et al. (2017) discuss causality between aging and urban agglomeration. They show that the promotion of public health policy may engender widening of wage differentials and widening of regional disparity.

The ambitious papers gathered in this special issue can be said to be an advanced study of regional science. I would be pleased if this special issue could contribute a little to the methodological diversity and extensive modernity of regional science.

\section{References}

Brehm S, Svensson J (2017) A fragmented environmental state? Analysing spatial compliance patterns for the case of transparency legislation in China. Asia-Pac J Reg Sci. https://doi.org/10.1007/ s41685-017-0058-9

Choi J, Kim I (2017) Regional total factor productivity and local employment growth: evidence from Korea. Asia-Pac J Reg Sci. https://doi.org/10.1007/s41685-017-0053-1

Fukushige M, Shi Y (2017) Intergovernmental fiscal relationship in China: a simple model based on the nonsymmetric Nash solution. Asia-Pac J Reg Sci. https://doi.org/10.1007/s41685-017-0040-6

Hori M (2017) Political regime change and cultural transmission of secularism. Asia-Pac J Reg Sci. https://doi.org/10.1007/s41685-017-0061-1

Kang S (2017) Long-term consequences of armed conflicts on poverty: the case of Cambodia. Asia-Pac J Reg Sci. https://doi.org/10.1007/s41685-017-0050-4

Kim I, Byeon J (2017) Discretionary prosecution of regulatory crimes: disproportionate emphasis and consequences to other serious crimes. Asia-Pac J Reg Sci. https://doi.org/10.1007/s41685-017-0052-2

Mori D, Takahashi S, Ikeda Y (2017) Compensation, punishment, and deterrence: survey on the purpose of tort damages in the case of a defective car accident in Japan. Asia-Pac J Reg Sci. https://doi.org/ $10.1007 / \mathrm{s} 41685-017-0059-8$

Naito T, Ikazaki D, Omori T (2017) Precautionary public health, aging and urban agglomeration. AsiaPac J Reg Sci. https://doi.org/10.1007/s41685-017-0056-y

Nakaizumi T, Yano S (2017) The soft budget constraint problem and hard budget solution of outward reinsurance markets. Asia-Pac J Reg Sci. https://doi.org/10.1007/s41685-017-0060-2

Sato S (2017) Referendums for secession domino and redistribution. Asia-Pac J Reg Sci. https://doi.org/ 10.1007/s41685-017-0054-0

Suzuki Y, Miah MD, Aung LH (2017) Challenges in the post-justice-seeking regime: the cases of Myanmar and Sri Lanka. Asia-Pac J Reg Sci. https://doi.org/10.1007/s41685-017-0049-X

Tanaka H (2017) Sustainability of global communities and regional risk governance. Asia-Pac J Reg Sci. https://doi.org/10.1007/s41685-017-0057-X 